\title{
Study Condition Lead Indicator
}

National Cancer Institute

\section{Source}

National Cancer Institute. Study Condition Lead Indicator. NCI Thesaurus. Code C94087.

Specifies whether this is the primary condition of a study. 